\title{
Leptospira sp. Strain Dimbovitza, First Isolate in Europe with Characteristics of the Proposed Genus Leptonema
}

\author{
S. BAZOVSKÁ, ${ }^{1}$ K. HOVIND-HOUGEN,${ }^{2 *}$ A. RUDIOVÁ, ${ }^{1}$ AND E. KMETY ${ }^{1}$ \\ Institute of Epidemiology, Medical Faculty of Komensky University, 88424 Bratislava, Czechoslovakia, ${ }^{1}$ and \\ Department of Biophysics, Statens Seruminstitut, Copenhagen, Denmark ${ }^{2}$
}

On the basis of serological, biological, and morphological characteristics of strain Dimbovitza cells, we concluded that this strain is a representative of the proposed genus Leptonema in the family Leptospiraceae.

Two leptospira-like spirochetes, illini strains 3055 and $\mathrm{A} 177$, have been isolated $(7,20)$. On the basis of their serological, biological, and morphological characteristics, these strains were recently proposed as representatives of a new genus, Leptonema, within the family Leptospiraceae (10).

During investigations on methods suitable for differentiating between pathogenic and saprophytic strains of Leptospira, we had the opportunity to examine a strain of another leptospiralike organism, strain Dimbovitza, which was isolated in Roumania in 1953. The characteristics of this strain were found to be similar in some respects to those of the two known illini strains. The results of a comparative study on strain Dimbovitza and illini strain 3055 are presented in this report.

\section{MATERIALS AND METHODS}

Strain Dimbovitza was originally isolated from the water of the Dimbovitza River in Roumania and was studied by Sefer et al. (16-19). This strain has been maintained in a modified Korthof medium (14).

Serology. Comparative serology studies were carried out with 27 serologically different strains of saprophytic leptospires and illini strain 3055 (Table 1). Furthermore, cells of strain Dimbovitza were tested with the 20 serogroup reference sera to pathogenic leptospires listed by Dikken and Kmety (6).

Biological characteristics. The following biological characteristics of strain Dimbovitza were determined: ability to grow in Trypticase soy broth (7), ability to grow in the presence of $225 \mu \mathrm{g}$ of 8-azaguanine per $\mathrm{ml}$ (13) and at $13^{\circ} \mathrm{C} \mathrm{(12),} \mathrm{and} \mathrm{ability} \mathrm{to} \mathrm{induce} \mathrm{hemolysis} \mathrm{of}$ sheep and rat blood cells $(1,5)$ and to hydrolyze phospholipids (2). The survival of the organisms in experimentally infected guinea pigs and golden hamsters was also examined (8).

Electron microscopy. Six-day-old cultures were centrifuged at $3,000 \times g$ for $20 \mathrm{~min}$, and the resulting pellet was suspended to a suitable density in SMC $(0.03 \%$ sucrose in redistilled water supplemented with $0.01 \mathrm{M}$ $\mathrm{MgCl}_{2}$ and $0.01 \mathrm{M} \mathrm{CaCl}_{2}$ ). Specimen grids were prepared from this suspension. Before staining, the cells on some grids were treated with drops of detergent (0.2\% Teepol or $2 \%$ sodium deoxycholate, both in redistilled water). All preparations were negatively stained with $1 \%$ ammonium molybdate $(\mathrm{pH} 7)$ by the multiple drop technique (11).

Electron microscopy was carried out by using routine methods (11).

\section{RESULTS}

Serology. Cells of strain Dimbovitza showed no significant relationship to any of the saprophytic strains with which they were compared, including illini strain 3055 (Table 1). None of the 20 serogroup reference sera to pathogenic strains agglutinated cells of strain Dimbovitza (Table 1).

Biological characteristics. The biological characteristics of strain Dimbovitza were similar to those of illini strain 3055. Both strains grew in Trypticase soy broth, grew at $13^{\circ} \mathrm{C}$, were resistant to $225 \mu \mathrm{g}$ of 8 -azaguanine per $\mathrm{ml}$ of medium, hemolyzed rat erythrocytes and lecithin, and survived for $4 \mathrm{~h}$ in guinea pigs and for $10 \mathrm{~h}$ in hamsters. Neither strain hydrolyzed sheep erythrocytes or sphingomyelin. Strain Dimbovitza and illini strain 3055 differed from the other saprophytic leptospires only by their ability to grow in Trypticase soy broth.

Electron microscopy. Cells of strain Dimbovitza showed a regular wavy outline and were 12 to $20 \mu \mathrm{m}$ long and $0.1 \mu \mathrm{m}$ wide. The wavelength was $0.5 \mu \mathrm{m}$. Each cell had two flagella, one inserted at each end (Fig. 1). In well-preserved cells each flagellum was entwined with the helical cell body for about six turns of the helix.

Cytoplasmic tubules with a diameter of about $8 \mathrm{~nm}$ were observed in cells accidentally damaged during preparation for electron microscopy (Fig. 2), as well as in cells treated with sodium deoxycholate. The cytoplasmic tubules appeared in bundles containing three to four tubules. The length of the tubules was roughly the same as the length of the flagella. One end of the bundle of tubules was frequently observed in close proximity to the insertion of the flagellum.

Flagella were detached from the cells after treatment with Teepol. The ultrastructures of the free flagella and their insertion regions were 
TABLE 1. Results of comparative agglutination tests with saprophytic strains of Leptospiraceae and illini strain 3055

\begin{tabular}{|c|c|c|c|}
\hline $\begin{array}{l}\text { Immune serum to } \\
\text { strain: }\end{array}$ & $\begin{array}{l}\text { Homologous } \\
\text { titer }\end{array}$ & $\begin{array}{l}\text { Titer with } \\
\text { strain } \\
\text { Dimbovitza }^{a}\end{array}$ & $\begin{array}{l}\text { Strain } \\
\text { Dimbovitza } \\
\text { immune } \\
\text { serum titer } \\
\text { with strain } \\
\text { listed }^{b}\end{array}$ \\
\hline illini 3055 & 12,800 & & \\
\hline Veldrat S173 & 12,800 & & \\
\hline Patoc 1 & 12,800 & & \\
\hline Sao Paulo & 50,000 & & \\
\hline Andaman CH11 & 50,000 & & \\
\hline Bovedo & 12,800 & & \\
\hline $\mathrm{Cau}$ & 12,800 & & \\
\hline Doberdo 1 & 12,800 & & \\
\hline RPE & 6,400 & & \\
\hline AM-20 & 25,000 & & \\
\hline Percedol 1 & 12,800 & & \\
\hline Bazovizza & 6,400 & & \\
\hline S. Giusto & 6,400 & & \\
\hline Farneti & 25,000 & 100 & \\
\hline Aurisina & 25,000 & 100 & 800 \\
\hline Botanica & 12,800 & & \\
\hline Monte Fiascone 2 & 12,800 & & \\
\hline Khoshamian & 12,800 & & \\
\hline Holland WaZ & 25,000 & & \\
\hline AM-6 & 6,400 & & \\
\hline AM-13 & 12,800 & & \\
\hline AR-18 & 12,800 & & \\
\hline Friuli 37 & 6,400 & & \\
\hline Friuli 44 & 12,800 & & \\
\hline Friuli 48 & 12,800 & & \\
\hline $\mathrm{V}-10$ & 6,400 & & \\
\hline V-1 & 25,000 & & \\
\hline V-15 & 6,400 & & \\
\hline
\end{tabular}

a Titers are reciprocal dilutions of the sera.

${ }^{b}$ The strain Dimbovitza homologous titer was 25,000 . identical to those of flagella isolated from leptospires $(3,14)$; i.e., a hook and a basal knob consisting of two pairs of disks connected by a rod could be distinguished (Fig. 3).

\section{DISCUSSION}

Cells of strain Dimbovitza are morphologically similar to cells of illini strains 3055 and A177. However, it is interesting that these strains differ in the structure of the basal complex of the flagella; i.e., in strain Dimbovitza cells the basal complexes are similar to those of leptospires and other gram-negative bacteria, whereas the corresponding structures on flagella of illini strains 3055 and A177 are similar to the structures in treponemes, borreliae, and gram-positive bacteria. Cytoplasmic tubules were observed in the cells of strain Dimbovitza, and the presence of these tubules is considered to be a morphological character of cells of Treponema and of the illini strains $(9,10)$.

The biological properties of illini strain 3055 and strain Dimbovitza indicate some similarity between these strains and the majority of the biflexa strains of Leptospira. There is also some resemblance concerning pathogenicity; the short survival time of the cells of the illini strains in guinea pigs and hamsters is noteworthy.

From a practical point of view, we emphasize that the illini strains grow well in Trypticase soy broth. This can be used as an important and practical test for the differentiation of these strains from strains of Leptospira biflexa.

Strain Dimbovitza is serologically different from illini strain 3055, and for this reason the proposed genus Leptonema must comprise at least two serotypes, illini and dimbovitza. We

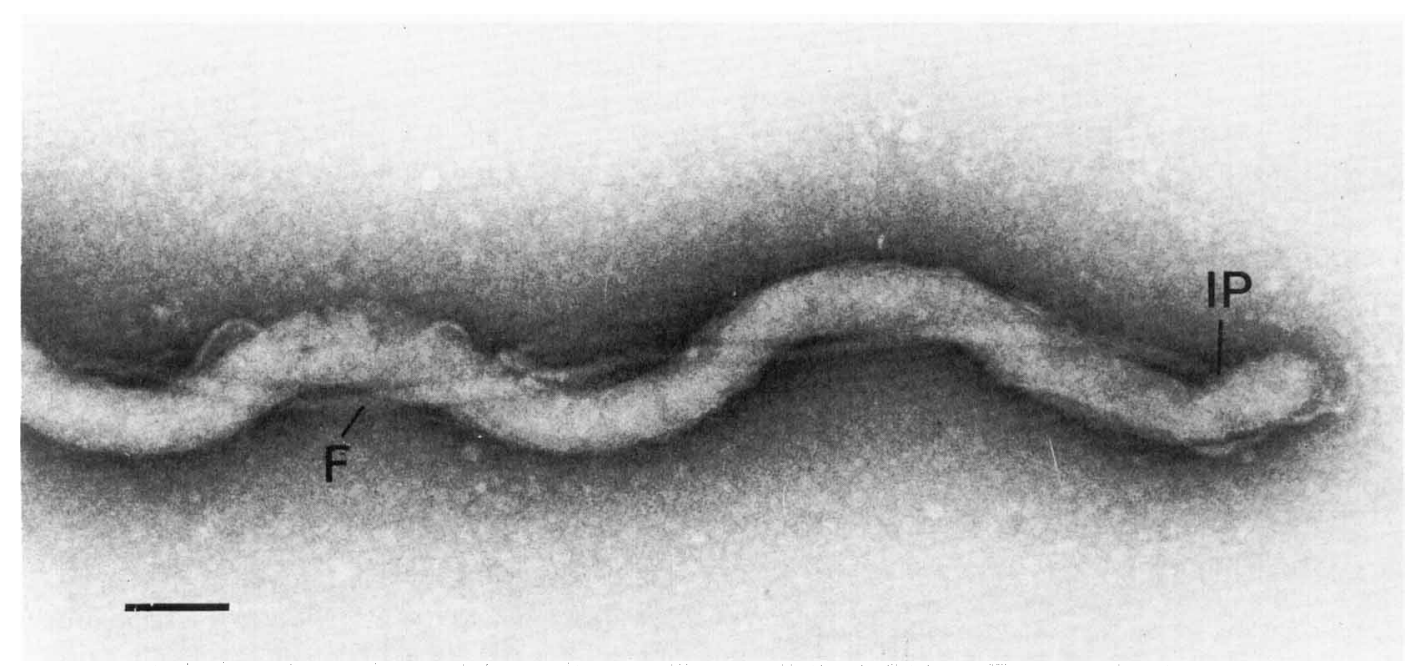

FIG. 1. End of a well-preserved strain Dimbovitza cell negatively stained with $1 \%$ ammonium molybdate $(\mathrm{pH}$ 7). The flagellum $(F)$ is entwined with the cell body. IP, Insertion point of the flagellum. Bar $=100 \mathrm{~nm}$. 


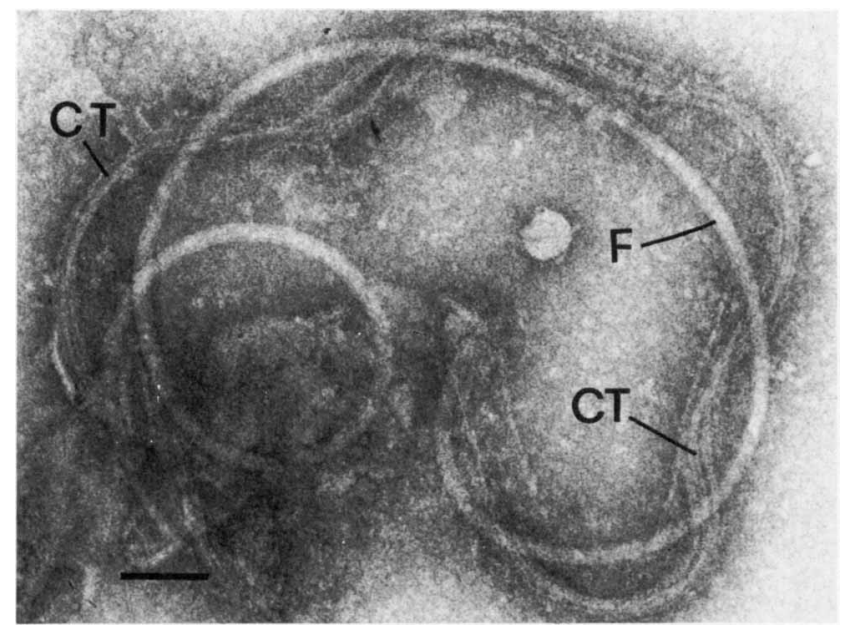

FIG. 2. End of a strain Dimbovitza cell accidently damaged during preparation for electron microscopy. The cell was negatively stained with $1 \%$ ammonium molybdate $(\mathrm{pH} 7)$. A bundle of four or five cytoplasmic tubules (CT) is apparent. F, Flagellum. Bar $=100 \mathrm{~nm}$.

anticipate that other strains of this genus will appear in the future.

The guanine-plus-cytosine contents of the deoxyribonucleic acids of cells of the species of Leptospira that have been examined are 35 to 41 mol\% (4), whereas the guanine-plus-cytosine contents of the deoxyribonucleic acids of the illini strains are 51 to $53 \mathrm{~mol} \%$ (7). Thus determination of the guanine-plus-cytosine content of the deoxyribonucleic acid of cells of strain Dim-

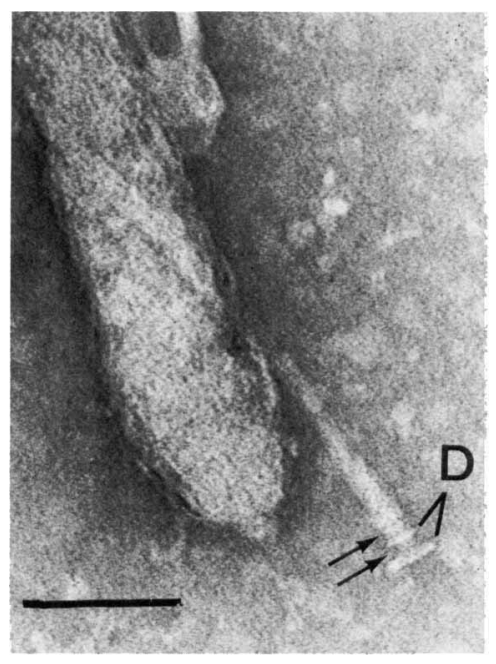

FIG. 3. Insertion part of a flagellum released from a strain Dimbovitza cell treated with Teepol and negatively stained with $1 \%$ ammonium molybdate $\mathrm{pH}$ 7). The basal complex consists of two pairs of disks (D) connected to each other and to the hook by two rods (arrows). Bar $=100 \mathrm{~nm}$. bovitza will be of importance in confirming the relationship of this strain to the illini strains.

Except for the isolation of two strains, illini strains 3055 and A177 (20), no information about the occurrence of strains of the proposed genus Leptonema has hitherto been published. Thus, strain Dimbovitza is the first known isolate of the proposed genus Leptonema from outside the United States.

\section{ACKNOWLEDGMENTS}

We thank A. Birch-Andersen for valuable help in the preparation of the manuscript. We also thank A. G. Overgaard for expert photographic work, L. G. Seidenfaden for secretarial assistance, and A. Thorborg for preparation of the final manuscript.

\section{LITERATURE CITED}

1. Bazovská, S. 1977. Hemolýza potkanich erytrocytov patogénnymi a saprofytárnymi kmeňmi leptospir. Cesk. Epidemiol. Mikrobiol. Immunol. 26:275-283.

2. Bazovská, S. 1978. Sfingomyelinázova aktivita leptospirovych kultúr. Cesk. Epidemiol. Mikrobiol. Immunol. 27:137-143.

3. Birch-Andersen, A., K. Hovind-Hougen, and C. BorgPetersen. 1973. Electron microscopy of leptospira. I. Leptospira strain Pomona. Acta Pathol. Microbiol. Scand. Sect. B 81:665-676.

4. Brendle, J. J., M. Rogul, and A. D. Alexander. 1974. Deoxyribonucleic acid hybridization among selected leptospiral serotypes. Int. J. Syst. Bacteriol. 24:204-214.

5. Chorvath, B. 1975. Some properties of leptospiral hemolysin. Biológia (Bratislava) 30:460-465.

6. Dikken, H., and E. Kmety. 1978. Serological typing methods of leptospires, p. 259-312. In T. Bergan and J. R. Norris (ed.), Methods in microbiology, vol. 11. Academic Press, Inc., London.

7. Hanson, L. E., D. N. Tripathy, L. B. Evans, and A. D. Alexander. 1974. An unusual leptospira, serotype illini (a new serotype). Int. J. Syst. Bacteriol. 24:355-357.

8. Havatá, Z., and S. Bazovská. 1974. The possibility of differentiation of pathogenic and saprophytic strains of leptospires by their survival in organisms of laboratory 
animals. Folia Fac. Med. Univ. Comenianae Bratisl. 12(Suppl.):163-169.

9. Hovind-Hougen, K. 1976. Determination by means of electron microscopy of morphological criteria of value for classification of some spirochetes, in particular treponemes. Acta Pathol. Microbiol. Scand. Sect. B Suppl. 255:20-30.

10. Hovind-Hougen, K. 1979. Leptospiraceae, a new family to include Leptospira Noguchi 1917 and Leptonema gen. nov. Int. J. Syst. Bacteriol. 29:245-251.

11. Hovind-Hougen, K., and A. Birch-Andersen. 1971. Electron microscopy of endoflagella and microtubules in Treponema Reiter. Acta Pathol. Microbiol. Scand. Sect. B 79:37-50.

12. Johnson, R. C., and V. Harris. 1967. Differentiation of pathogenic and saprophytic leptospires. I. Growth at low temperatures. J. Bacteriol. 94:27-31.

13. Johnson, R. C., and P. Rogers. 1964. Differentiation of pathogenic and saprophytic leptospires with 8-azaguanine. J. Bacteriol. 88:1618-1623.

14. Kmety, E. 1957. Návrh na štandartnú metódu aglutinolyzinovej reakcie pri leptospirózach. Cesk. Epidemiol. Mikrobiol. Immunol. 6:372-377.
15. Nauman, R. K., S. C. Holt, and C. D. Cox. 1969. Purification, ultrastructure and composition of axial filaments from Leptospira. J. Bacteriol. 98:264-280.

16. Sefer, M. 1965. Contributions à l'étude de la constitution chimique de la structure antigénique et du pouvoir pathogène des leptospires. Arch. Roum. Pathol. Exp. Microbiol. 24:583-598.

17. Sefer, M. 1975. Ecological investigations on acvicola leptospira isolated in Romania, p. 49-55. In M. Sefer (ed.), Leptospirosis, leptospira and other spirocheta. Cantacuzino Institute, Bucharest.

18. Sefer, M. 1975. Growth and multiplication specific serum inhibition test applied to acvicola leptospira, p. 77-83. In M. Sefer (ed.), Leptospirosis, leptospira and other spirocheta. Cantacuzino Institute, Bucharest.

19. Sefer, M., C. Verenca, and C. Sandru. 1973. Metoda competitiei pentru controlul si purificarea culturilor de leptospire acvicole. Microbiol. Parazitol. Epidemiol. 18:469-474.

20. Tripathy, D. N., and L. E. Hanson. 1973. Studies of Leptospira illini, strain 3055: immunologic and serologic determinations. Am. J. Vet. Res. 34:563-565. 